Revista Latinoamericana de la Papa 21 (1): 22 - 38

ISSN: $1853-4961$

http://www.papaslatinas.org/revista.html

\title{
Organic production of native potato landrace "pintaboca" (Solanum stenotomum Juz. \& Bukasov) in Bolivia: experimenting planting times and cultivation strategies
}

\author{
G. Luziatelli ${ }^{1}$, M. Sørensen ${ }^{2}$, S.-E. Jacobsen ${ }^{3}$, N. Ortuño ${ }^{4}$, A. Angulo ${ }^{5}$, F. Terrazas ${ }^{6}$
}

Received: 02/10/2016

Accepted: 04/04/2017

Accessible on line: June 2017

\begin{abstract}
Summary
In the municipality of Colomi, in the highlands of Bolivia, market pressure leads small scale farmers to substitute their native landraces with commercial potato varieties. Organic cultivation might offer a channel for selling native potatoes to an emerging industry of coloured native potato crisps. Nevertheless, as the area is endemic for late blight (Phytophthora infestans), adequate cultivation practices that allow organic production must be defined. The present experiment compared four cultivation strategies (two organic, which included the use of beneficial microoorganisms applied in the soil and through foliar spray, one conventional, which included cymoxanil and mancozeb based fungicides and a control with the same soil treatment as the organic strategies but no foliar spray) and two planting dates (early and main season planting) on a native potato landrace locally known as 'pintaboca' (Solanum stenotomum). Our results showed that early planting resulted in significantly higher yields, although the area under disease progress curve (AUDPC) of late blight did not differ significantly between planting dates. The lower yields in the plot planted during the main season were mainly due to the combined incidence of early and late blight. There was no significant difference in yields and quality of the tubers cultivated with conventional, organic or control treatment, with the exception that the largest tuber size category was produced only in the conventional treatment. We conclude that farmers in Colomi who want to shift to organic cultivation of the landrace 'pintaboca' at altitudes around 3,300 $\mathrm{m}$ a.s.l. could benefit from practicing early planting, although additional trials covering several seasons are needed to confirm our results.
\end{abstract}

Palabras clave adicionales: Phytophthora infestans, biofungicide, organic agriculture.

Corresponding author. Electronic mail: gaia.luziatelli@gmail.com

PhD Candidate, Department of Plant and Environmental Sciences, Copenhagen University. Copenhagen.

Associate Professor, Department of Plant and Environmental Sciences, Copenhagen University.

Copenhagen.

3 Associate Professor, Department of Plant and Environmental Sciences, Copenhagen University.

Copenhagen.

4 Lecturer and researcher, Faculty of Agronomy, UMSS. Cochabamba.

5 Researcher, Genetic improvement of Andean crops and vegetables. PROINPA. Cochabamba.

6 Coordinator of Project "Biocultura y Cambio Climatico de Colomi", PROINPA. Cochabamba. 


\section{Producción orgánica de papas nativas "pintaboca" (Solanum stenotomum Juz. \& Bukasov) en Bolivia: experimentando tiempos de siembra y estrategias de cultivo \\ Resumen}

En el municipio de Colomi, en las tierras altas de Bolivia, la presión del mercado lleva a los pequeños agricultores a sustituir sus cultivares nativos por cultivares comerciales de papa. El cultivo orgánico podría ofrecer un canal para la venta de papas nativas a una industria emergente de papas fritas de color. Sin embargo, como el área es endémica para el tizón tardío (Phytophthora infestans), deben definirse prácticas de cultivo adecuadas que permitan la producción orgánica. El presente experimento comparó cuatro estrategias de cultivo (dos orgánicas, que incluyeron el uso de microorganismos beneficiosos aplicados en el suelo y a través de pulverización foliar, uno convencional, que incluía fungicidas basados en cymoxanil y mancozeb y un control con el mismo tratamiento en el suelo que las estrategias orgánicas pero sin pulverización foliar) y dos fechas de siembra (siembra temprana y de temporada principal) en una papa nativa localmente conocida como 'pintaboca' (Solanum stenotomum). Nuestros resultados mostraron que la siembra temprana dio lugar a rendimientos significativamente más altos, aunque el área bajo curva de progreso de la enfermedad (AUDPC) del tizón tardío no difirió significativamente entre las fechas de siembra. Los rendimientos más bajos en la parcela plantada durante la temporada principal se debieron principalmente a la incidencia combinada de tizón temprano y tardío. No hubo diferencias significativas en los rendimientos y calidad de los tubérculos cultivados con el tratamiento convencional, orgánico o de control, con la excepción de que la categoría de tamaño de tubérculo más grande se produjo sólo en el tratamiento convencional. Llegamos a la conclusión de que los agricultores de Colomi que desean cambiar al cultivo orgánico del cultivar "pintaboca" a altitudes alrededor de 3,300 m.s.n.m. podrían beneficiarse de practicar la siembra temprana, aunque se necesitan ensayos adicionales que abarquen varias temporadas para confirmar nuestros resultados.

Palabras clave adicionales: Phytophthora infestans, biofungicida, agricultura orgánica.

\section{Introduction}

The area cultivated with potatoes in Bolivia accounts for 130,000 ha annually of which 26,000 ha are planted in the department of Cochabamba. This is the third largest department by order of cultivated area with this crop following the departments of $\mathrm{La} \mathrm{Paz}$ and Oruro (Coca-Morante, 2012). The average yearly production of potatoes in the Department of Cochabamba in the period 2005-2007 was 136,632 tonnes (Zeballos et al., 2009). The climate in the areas of highland agriculture in Bolivia is influenced by their distance from the transition zone between the Eastern Andean and the Amazonian regions. The
Central Highland, being distant from the transition zone, is characterized by a dry climate, ideal for the cultivation of Andean seed crops such as quinoa (Chenopodium quinoa Willd.) and cañahua (Chenopodium pallidicaule Aellen). The municipality of Colomi (province Chapare, Cochabamba department) is situated in the centremeridional part of the Eastern Andean mountain range, delimited by the subtropical region of the Yungas of Chapare to the North and the Cochabamba valleys to the South (CocaMorante, 2012). It has a cold and humid climate ideal for the cultivation of Andean tubers. Colomi is a hotspot of 
agro-biodiversity with environmental, social and cultural characteristics that favour the conservation of Andean tubers' landraces. However, their production is exposed to risks, such as external market pressures, which lead to the replacement of native potato varieties with commercial ones (García et al., 2003). Due to its climate, it is also an area with high incidence of Phytophthora infestans (Mont.) de Bary, the causal agent of potato late blight. This pathogen, which caused the Great Irish Famine in the middle of the $19^{\text {th }}$ century, is the most severe potato disease worldwide (Henfling, 1987; Haverkort et al., 2009). In cool and wet weather conditions, the swimming zoospores of this oomycete infect all plant organs. In optimal weather conditions with susceptible varieties, the disease can develop very quickly affecting entire fields, which results in severe yield losses (Henfling, 1987). Local farmers normally make effort to contain severe losses relying on the application of synthetic fungicides (CocaMorante, 2012). This can have detrimental effects on the health of the small farmers, especially the less educated and poorest, as many highly and moderately hazardous pesticides are sold in the Andes, and they are applied and stored without proper safety measures (Orozco et al., 2009; Cole et al., 2011). Organic agriculture, intended as "farming systems where the use of pesticides, herbicides and chemical fertilizers is prohibited, [...] which rely on crop rotations, natural nitrogen fixation, biologically active soil, recycled farm manure and crop residues, and biological or mechanical weed and pest control" (Bengtsson et al., 2005), could offer a solution for reducing the exposure of local farmers and consumers to hazardous substances while preserving the quality of the soil and water through increased biodiversity (Altieri, 1999; Mäder et al., 2002). Moreover, producing organically might open possibilities for the local farmers to improve their livelihoods by selling their crop with a price premium to national or international markets, for example to be transformed into organic coloured crisps (chips in U.S. English) and exported to specialized markets in Europe or the U.S.. An example of successful marketing of native potatoes has been documented by the Papa Andina Project and the T'ikapapa brand in Peru (Manrique et al., 2011). Nevertheless, to achieve economically sustainable yields with organic farming, the risk of late blight needs to be reduced through the adoption of different cultivation practices. In particular, use of tolerant landraces, early planting and application of biofertilizers and bio-fungicides authorized in organic agriculture are practices normally used by organic growers. In Colomi the local native potato landrace 'pintaboca' (Solanum stenotomum Juz. \& Bukasov) showed medium susceptibility to the pathogen Phytophthora infestans (Cadima et al., 2004) and performed well when fried, therefore was chosen for this experiment.

The bio-fertilizers and bio-fungicides tested in this study produced by Biotop s.r.l., are based on the beneficial microorganisms Bacillus subtilis (Ehrenberg) Cohn, Bacillus amyloliquefaciens (Fukumoto) Priest et al. and Trichoderma spp. which increase the nutrients uptake from the soil and the plant defence from pathogens through a mechanism of induced systemic resistance (Kloepper et al., 2004; Ortuño et al., 2010; Borriss, 2011; Chowdappa et al., 2013). Bacillus subtilis, Bacillus amyloliquefaciens and Trichoderma spp. have been proven to effectively reduce the effects of Helminthosporium solani Durieu \& Mont. 
and Phytopthora infestans in potatoes (Kuepper and Sullivan, 2004; Stephan et al., 2005; Mamani-Rojas et al., 2012) and to increase tuber production (Franco et al., 2011). Additionally, two species of Vesicular-arbuscular mycorrhizae (VAM) fungi (Glomus fasciculatum and Glomus etunicatum) were added to the soil in the organic treatments. The mycorrhizae produced by the association between the fungi and plant roots are known to enhance the absorption of plant mineral nutrients, especially phosphates, and contribute to soil aggregate formation (Sullia, 1991; Mäder et al., 2002).

The objective of this study was to test whether early planting of native potatoes in August compared to the main seasonal planting in October is an effective method to reduce the severity of late blight and is therefore a recommendable practice for local organic cultivation. At the same time, conventional vs. organic cultivation strategies were tested for their yield and effectiveness in protecting the tubers against pathogens.

\section{Materials \& Methods}

\section{Study site}

The experiment was carried out during the growing season August 2012/March 2013 in fields belonging to farmers in the district of Colomi, located $63 \mathrm{~km}$ East of the city of Cochabamba. Plot locations and soil characteristics at time of planting are indicated in Table 1. The first plot was planted on August $3^{\text {rd }} 2012$ and harvested on January $28^{\text {th }} 2013$ in the locality called Balcon-Sayt'o Loma. The plot was previously a 'puruma' soil, which means that it had not been cultivated for more than five years and was covered by the prevailing vegetation of the area: 'paja brava' or 'ichu' (Stipa ichu Kunth), 'th'ola' (Baccharis spp.), 'muña' (Satureja parviflora C.Presl) and the 'ch'ilka' (Baccharis dracunculifolia DC.) The second plot was planted on October $5^{\text {th }} 2012$ and harvested on March $6^{\text {th }} 2013$ in the locality Pico Central. The plot had been cultivated the previous year with oca (Oxalis tuberosa Molina) and ullucu (Ullucus tuberosus Caldas). 
Table 1. Plot locations, planting and harvesting dates and soil characteristics at time of planting.

\begin{tabular}{lll}
\hline & $\begin{array}{l}\text { Balcon-Sayt'o } \\
\text { Loma } \\
\text { (Early planting) }\end{array}$ & $\begin{array}{l}\text { Pico Central } \\
\text { (Normal planting) }\end{array}$ \\
\hline Coordinates & S 17 12.310 & S 17 19.369 \\
Altitude & W 65 57.975 & W 65 56.620 \\
Date planted & 3,367 m.a.s.1 & 3,393 m.a.s.1. \\
Date harvested & $3 / 8 / 2012$ & $5 / 10 / 2012$ \\
Soil characteristics & $28 / 01 / 2013$ & $6 / 3 / 2013$ \\
Texture & & \\
\% Clay & Loam & Loam \\
\% Loam & 11 & 20 \\
\% Sand & 46 & 46 \\
pH 1:2.5 (soil/water) & 43 & 34 \\
E.C. 1:2.5 (soil/water) & 4.3 & 5.3 \\
Interchangeable cations (me/100g) & 0.195 & 0.367 \\
Potassium & 0.87 & 1.31 \\
Organic Matter \% & 15.29 & 8.36 \\
Total nitrogen \% & 0.723 & 0.513 \\
Available phosphorus (ppm) & 0.9 & 20 \\
\hline
\end{tabular}

\section{Treatments}

Field monitoring and treatments' applications were performed by a research assistant employed for the time of the experiment, while weeding and hilling were performed by the farmers who owned the plots. Two organic strategies $\left(\mathrm{O}_{1}\right.$ and $\left.\mathrm{O}_{2}\right)$ included the use at planting time and 'in-season' of the following bio-fertilizers and biofungicides, according to the modality described in Table 2: 'Biobacillus'(Bacillus subtilis and Bacillus amyloliquefaciens 4 × $10^{9} \mathrm{ufc} / \mathrm{gr}$ at $0,01 \%$ concentration), 'Mibac'(Bacillus subtilis $4 \times 10^{9} \mathrm{ufc} / \mathrm{gr}$ at $0.01 \%$ concentration, Glomus fasciculatum and Glomus etunicatum 30 spores/gr at $0,02 \%$ concentration) and 'Tricobal'(Bacillus subtilis and Bacillus amyloliquefaciens 4 $\mathrm{x} \quad 10^{9} \mathrm{ufc} / \mathrm{gr}$ at $0.01 \%$ concentration, Trichoderma koningiopsis and Trichoderma hardzianum 1 x $10^{12}$ spores/gr at $20 \%$ concentration ), trademarks of BIOTOP s.r.l.;'Terra Biosa', produced by the company BIOSA®, which contains a mixture of various microorganisms, including Lactobacillus sp., Bifidobacterium animalis, Streptococcus thermophiles, Leuconostoc pseudomesenteroides, Rhrodopseudomonas plustris, Saccharomyces cerevisise and herb extracts diluted in water and sugar molasses; 'Timorex Gold ${ }^{\circledR}$ ' by Stockton Group, produced by BIOMOR Israel, which contains tea tree (Melaleuca alternifolia) oil at $22.25 \%$. 
Table 2. Scheme of the treatments applied at sowing time and on the foliage in each of the strategies.

\begin{tabular}{|c|c|c|}
\hline Strategy & $\begin{array}{l}\text { Products applied to the soil at } \\
\text { sowing time }\end{array}$ & $\begin{array}{l}\text { Weekly foliar sprays starting from week } \\
11 \text { after sowing }\end{array}$ \\
\hline $\mathbf{O}_{1, \text { Organic } 1}$ & $\begin{array}{l}\text { Tricobal (2 kg/ha)+ Mibac }(20 \\
\mathrm{kg} / \mathrm{ha})+ \text { Organic manure }(10.7 \mathrm{t} / \mathrm{ha})\end{array}$ & $\begin{array}{l}\text { Biobacillus }(2 \mathrm{~kg} / \mathrm{ha}) \text { and Terra Biosa }{ }^{\circledR}(2 \\
\mathrm{L} / \mathrm{ha}) \text { at alternate weeks }\end{array}$ \\
\hline $\mathrm{O}_{2, \text { Organic } 2}$ & $\begin{array}{l}\text { Tricobal (2kg/ha)+ Mibac }(20 \\
\mathrm{kg} / \mathrm{ha})+ \text { Organic manure }(10.7 \mathrm{t} / \mathrm{ha})\end{array}$ & $\begin{array}{l}\text { Timorex ( } 2 \text { litres/ha) and Terrabiosa ( } 2 \mathrm{~L} / \mathrm{ha}) \\
\text { at alternate weeks }\end{array}$ \\
\hline $\mathbf{T}_{\mathbf{0}}$, Control & $\begin{array}{l}\text { Tricobal (2 kg/ha)+ Mibac (20 } \\
\mathrm{kg} / \mathrm{ha})+ \text { Organic manure }(10.7 \mathrm{t} / \mathrm{ha})\end{array}$ & No treatment \\
\hline $\mathbf{T}_{\mathfrak{c}, \text { Conventional }}$ & Chicken manure (15.7 t/ha) & $\begin{array}{l}\text { Bordeaux mixture at week } 13 \text {, Curathane } \\
50 \%+\text { Dithane } 50 \% \text { weeks } 14 \text { and } 15 \text {, } \\
\text { Coraza weeks } 16 \text { and } 17\end{array}$ \\
\hline
\end{tabular}

Tricobal was diluted in water and applied on the seed potatoes before planting, while Mibac was applied in dry form on top of manure at sowing time. The other products were applied with a backpack sprayer during the growing season, as indicated in Table 2. The conventional strategy normally used by the farmers of the area (Tc) included the applications of chicken manure at planting time and treatments on the foliage made with: Bordeaux Mixture made with a copper sulfate base and calcium oxide solution in a 1 to 9 ratio, as indicated by DonaireEguívar \& Garcia (2006); Curathane ®72WP (7 gr/L), cymoxanil 8\% + mancozeb 64\%, Dithane® M-45 (10,5 gr/l), mancozeb $75 \%$ MP by DOW Agroscience; Coraza (4.5 g/L), cymoxanil + mancozeb by Serfi S.A. The products were applied by backpack sprayer. The control $\left(\mathrm{T}_{0}\right)$ consisted in the same treatment at planting time as $\mathrm{O}_{1}$ and $\mathrm{O}_{2}$, but no treatment 'in-season' on the foliage (see Table 2). We used this treatment as a control to verify whether there had been any effect by the foliar sprays applied during the growth season to the organic treatments.

\section{Experimental design}

The design of the experiment consisted in a randomized block with four treatments $\left(\mathrm{O}_{1}, \mathrm{O}_{2}, \mathrm{~T}_{0}\right.$ and $\left.\mathrm{T}_{\mathrm{c}}\right)$ and four blocks. This set up was repeated in two separate plots owned by farmers at the same approximate altitude of 3,380 m.a.s.l., at different planting times. The comparison was possible using the model series of experiments where the lots were the localities and the blocks within each locality were evaluated as nested effect since the blocks vary from locality to locality. The model was: Performance $=$ Locality + Block (Locality) + Strategy + Locality * Strategy + error. Each experimental unit consisted of 5 rows at $0.70 \mathrm{~m}$ distance between rows. In each row of $5 \mathrm{~m}$, opened by hand-hoe, 17 tubers were planted at $0.30 \mathrm{~m}$ of distance and the three central rows were harvested for yield assessment (excluding the first and last plant, i.e. borders). The native potato locally known as 'Pintaboca' (a landrace of Solanum stenotomum) was 
chosen because of its medium susceptibility to late blight infection as well as for its attractive colour and adaptability to be transformed in potato crisps, which makes it a marketable landrace.

\section{Weekly monitoring}

The early planted plot (Balcon) was monitored every week starting from week 11 after planting until week 23 , while the plot planted at normal time (Pico Central) was monitored from week 8 until week 22. The observed parameters were: percentage of emergence, height of plants, incidence and severity of late blight (Phytophthora infestans), early blight (Alternaria solani). To determine the severity of the late blight on the foliage we used the international scale from 1 to 9 (1=0\% no lesion observed and
$9=100 \%$ all the leaflets and stems wilted) mentioned by Gabriel et al. (2010).

The weekly severity measurements of affected foliage were then used to calculate the Area Under Disease Progress Curve (AUDPC) of late blight and early blight, which is a quantitative summary of disease intensity over time (Madden et al., 2007).

\section{Harvest}

The early planted field was harvested on $28^{\text {th }}$ January 2013, i.e. 178 days after planting (DAP) and the normally planted field on the $6^{\text {th }}$ of March 2013, i.e. 152 DAP. The potato tubers of the various treatments were separated, and divided by size and weight into the locally known categories: Chapara, Qolque, Machu Murmu, C'hili murmu and C'hili (Table $3)$.

Table 3. Local categories of potato size in the indigenous Quechua language. Average weight, length and diameter were calculated from samples of the potatoes harvested in our experiment.

\begin{tabular}{llll}
\hline Local name & $\begin{array}{l}\text { Average } \\
\text { weight }\end{array}$ & $\begin{array}{l}\text { Average } \\
\text { length }\end{array}$ & Average diameter \\
\hline Chapara & g/tuber & $\mathrm{cm} /$ tuber & $\mathrm{cm} /$ tuber \\
Qolque & 136.6 & 14.3 & 4.0 \\
Machu murmu & 95.0 & 11.3 & 4.0 \\
C'hilimurmu & 56.6 & 7.0 & 3.1 \\
C'hili & 35.0 & 5.2 & 3.0 \\
\hline
\end{tabular}

\section{Participatory Evaluation}

On the harvest day of the early planted plot, the family who had provided the land plus four other farmers performed an evaluation of the yield of the four strategies. The harvested potatoes, divided according to strategy and size categories, were placed in front of four signs listing the products that had been used at planting time and through the growing season, with the respective total cost. This was calculated by multiplying the price per litre or per kilogram of the products utilized per the quantity utilized in each treatment (four plots of $17.5 \mathrm{~m}^{2}$ ). No other costs (e.g. men labour) were considered. Then the farmers were asked to rank the four treatments on a scale from 1 to 4 , where 1 was the best and 4 the poorest, according to their preference considering quantity and quality of the 
tubers and price. The cost of the treatments was the following (cost of treatment of four plots of $17.5 \mathrm{~m}^{2}$ each): Strategy $\mathrm{O}_{1}=122 \mathrm{BOB}$, Strategy $\mathrm{O}_{2}=$ $120 \mathrm{BOB}, \mathrm{T}_{\mathrm{c}}=120 \mathrm{BOB}, \mathrm{T}_{0}=110 \mathrm{BOB}$. $(\mathrm{BOB}=$ Bolivian Boliviano, the local currency, corresponding to 0.14 USD)

\section{Tubers evaluation}

A sample of 10 tubers from each experimental unit (EU) (16 EU, 160 tubers) was analyzed for incidence and severity of the diseases: late blight (Phytophthora infestans), black scurf (Rhizoctonia solani) and silver scurf (Helminthosporium solani), being these common diseases affecting potato tubers in the area (of these, only Phytophthora infestans was among the diseases evaluated on the aerial parts). The scale used for black scurf ranged from 1 to 6 as reported in Gabriel et al. (2010), the scale for silver scurf ranged from 0 to 4 adapted from the evaluation scale used for Streptomyces scabies in Gabriel et al. (2010) and the scale for Phytophthora infestans ranged from 0 to 10 .

\section{Results}

Potato yield in the study sites was influenced by the planting time. Our data showed a highly significant difference $(p<0.01)$ between the yields of the plot planted in August (average $16.78 \mathrm{t} / \mathrm{ha}$ ) and the yields of the plots planted in October (average $1.97 \mathrm{t} / \mathrm{ha}$ ) (Figure 1).

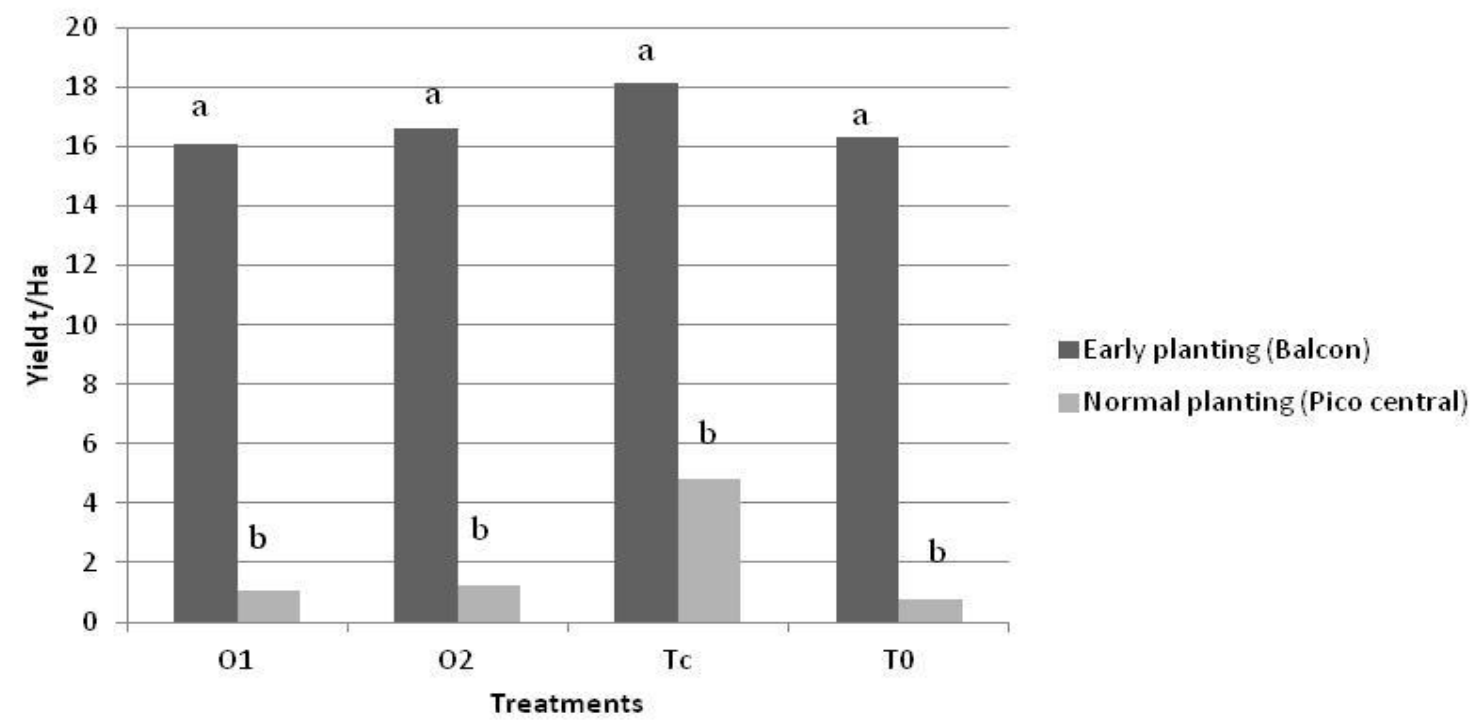

Figure 1. Average yield of conventional $\left(\mathrm{T}_{\mathrm{c}}\right)$ and organic $\left(\mathrm{O}_{1}, \mathrm{O}_{2}\right)$ cultivation systems $\left(\mathrm{T}_{0}\right.$ $=$ control) applied in two different planting seasons. The early planting was done on the $3^{\text {rd }}$ August 2012 while the normal planting was done on the $5^{\text {th }}$ October 2012.

The yield variation was highly significant for all the potato size categories (Table 7). Of the 45 plants that should have been harvested in each experimental unit (17 tubers $\times 3$ central rows minus the first and last plant in each row) the mortality rate was very different between early planting and normal planting as shown in Table 4. In the plot planted in August, the average mortality rate was $6.11 \%$, with no significant difference between the four strategies. In the plot planted in October 
the average mortality rate was $63.88 \%$ and there was a significant difference between strategies, where the conventional one $T_{c}$ reported the lowest mortality, while the organic strategy $\mathrm{O}_{2}$ the highest, due to the major incidence of early blight in this strategy.

Table 4. Mortality rates in the early planted and in normal planted plots.

The rate was calculated as a percentage of the 45 plants that should have been harvested in each experimental unit at harvest time.

\begin{tabular}{lllll}
\hline Strategy & Early planting & \multicolumn{2}{c}{ Normal planting } \\
\hline $\mathrm{n}=45$ & & & $\mathrm{ab}$ \\
\hline Organic 1 & 7.78 & $\mathrm{a}$ & 66.67 & $\mathrm{ab}$ \\
$\mathrm{T} 0$, Control & 6.67 & $\mathrm{a} 70.00$ & $\mathrm{~b}$ \\
$\mathrm{Tc}$, Conventional & 6.11 & $\mathrm{a}$ & 40.00 & $\mathrm{a}$ \\
Organic 2 & 3.89 & $\mathrm{a} 78.89$ & $\mathrm{a}$
\end{tabular}

Means with the same letter are statistically equal $(\mathrm{p}<0.05)$

The cultivation strategies $\left(\mathrm{T}_{\mathrm{c}}, \mathrm{O}_{1}, \mathrm{O}_{2}\right.$ and $\mathrm{T}_{0}$ ) alone could not explain the yield variation, with the exception of the tubers of the biggest size 'chapara', which only grew in the $T_{c}$ plots (Tables 5, 6).

Table 5. Yields (t/ha) divided according to local size categories of four conventional and organic systems under early planting conditions.

\begin{tabular}{lllllll}
\hline Strategy & Total yield & Chapara & Qolque & Machu murmu & $\begin{array}{l}\text { Ch'ili } \\
\text { murmu }\end{array}$ & Ch'ili \\
\hline & & & (t/ha) & & $4.118 \mathrm{a}$ & $0.871 \mathrm{a}$ \\
\hline O1 & $6.057 \mathrm{a}$ & $0 \mathrm{~b}$ & $5.709 \mathrm{a}$ & $5.235 \mathrm{a}$ & $3.819 \mathrm{ab}$ & $1.209 \mathrm{a}$ \\
$\mathrm{O} 2$ & $6.629 \mathrm{a}$ & $0 \mathrm{~b}$ & $6.762 \mathrm{a}$ & $4.714 \mathrm{a}$ & $3.370 \mathrm{ab}$ & $1.264 \mathrm{a}$ \\
T0 & $6.338 \mathrm{a}$ & $0 \mathrm{~b}$ & $6.577 \mathrm{a}$ & $5.097 \mathrm{a}$ & $2.342 \mathrm{~b}$ & $0.781 \mathrm{a}$ \\
Tc & $8.105 \mathrm{a}$ & $4.365 \mathrm{a}$ & $5.767 \mathrm{a}$ & $4.617 \mathrm{a}$ & & \\
\hline
\end{tabular}

Means with the same letter are statistically equal $(\mathrm{p}<0.01)$

Table 6. Yields (t/ha) divided according to local size categories of four conventional and organic systems under main planting conditions.

\begin{tabular}{lllllll}
\hline Strategy & Total yield & Chapara & Qolque & Machu murmu & Ch'ili murmu & Ch'ili \\
\hline \multicolumn{7}{c}{} \\
\hline O1 & $1.049 \mathrm{a}$ & $0 \mathrm{a}$ & $0.024 \mathrm{a}$ & $0.271 \mathrm{ab}$ & $0.182 \mathrm{~b}$ & $0.460 \mathrm{~b}$ \\
O2 & $1.259 \mathrm{a}$ & $0 \mathrm{a}$ & $0.124 \mathrm{a}$ & $0.266 \mathrm{ab}$ & $0.275 \mathrm{~b}$ & $0.398 \mathrm{~b}$ \\
T0 & $0.762 \mathrm{a}$ & $0 \mathrm{a}$ & $0.043 \mathrm{a}$ & $0.097 \mathrm{~b}$ & $0.212 \mathrm{~b}$ & $0.395 \mathrm{~b}$ \\
Tc & $4.818 \mathrm{a}$ & $0.116 \mathrm{a}$ & $0.602 \mathrm{a}$ & $1.107 \mathrm{a}$ & $0.936 \mathrm{a}$ & $1.461 \mathrm{a}$ \\
\hline
\end{tabular}

Means with the same letter are statistically equal $(\mathrm{p}<0.01)$ 
Our results show no significant difference in AUDPC of late blight caused by Phytophthora infestans for the two planting dates. In the plot planted in August (early planting) late blight was first recorded on the $7^{\text {th }}$ November 2012 (100 days after planting) and reached $75 \%$ (as average of all treatments) around 150 DAP. In comparison, the plot planted in October (main planting season) was first infected by early blight caused by Alternaria solani and then by late blight caused by Phytophthora infestans. Early blight was first recorded on $13^{\text {th }}$ December 2012 (69 DAP) and the disease reached $75 \%$ severity around 123 DAP. Late blight was first recorded on $24^{\text {th }}$ January 2013 (111 DAP) and reached $20.42 \%$ infection 147 DAP. At this point the plot was already heavily damaged by early blight, and the effects of the two diseases caused the very high mortality rate shown in Table 4. According to the measurements in the metereologic station of Colomi, the plot planted in August received in total $243 \mathrm{~mm}$ of rain, while the plot planted in October received 303 $\mathrm{mm}$ of rain (Senamhi, 2013). The month with the highest number of rainy days (15) was December with a total of 93.7 $\mathrm{mm}$ of rain, where the heaviest rainfalls happened on the $4^{\text {th }}, 8^{\text {th }}, 17^{\text {th }}$ and $19^{\text {th }}$ of the month. The years 2012 and 2013 recorded a total amount of rain of 572 and $444.4 \mathrm{~mm}$ respectively, where the average for the area based on data from 1977 to 2015 is $602.3 \mathrm{~mm}$ with a standard deviation of $124.69 \mathrm{~mm}$. So the values for 2012, which included the month with highest rainfall, are within the normality. In the early planted plot there was a highly significant $(\mathrm{p}<0.01)$ relation between strategies and AUDPC of Phytophthora infestans. The AUDPC in the Tc strategy was significantly lower than that of the other strategies. On the contrary, there was no significant relation between strategies and AUDPC of Phytophthora infestans in the main planting season (Table 8).

Table 7. Comparison of total yield of each potato size cathegory between early and main planting.

\begin{tabular}{lllllll}
\hline Planting date & Total yield & Chapara & Qolque & Machu murmu & C'hili murmu & Ch'ili \\
\hline & & \multicolumn{5}{c}{$(\mathrm{t} / \mathrm{ha})$} \\
\hline Early planting & $16.78 \mathrm{a}$ & $0.609 \mathrm{a}$ & $6.19 \mathrm{a}$ & $4.91 \mathrm{a}$ & $3.376 \mathrm{a}$ & $1.03 \mathrm{a}$ \\
Main planting & $1.97 \mathrm{~b}$ & $0.028 \mathrm{~b}$ & $0.18 \mathrm{~b}$ & $0.39 \mathrm{~b}$ & $0.358 \mathrm{~b}$ & $0.68 \mathrm{~b}$ \\
\hline
\end{tabular}

Means with the same letter are statistically equal $(\mathrm{p}<0.01)$

Table 8. Area under disease progress curve (AUDPC) for late blight (Phytophthora infestans) on the potato landrace "pintaboca', assessed under four control strategies in early planting and main planting season. The comparison was performed between control strategies in each planting season.

\begin{tabular}{lll}
\hline & AUDPC late blight & \\
\hline Strategy & Early planting & Main planting \\
\hline O1 & $42.46 \mathrm{~b}$ & $48.32 \mathrm{a}$ \\
O2 & $42.75 \mathrm{~b}$ & $46.67 \mathrm{a}$ \\
T0 & $42.70 \mathrm{~b}$ & $38.95 \mathrm{a}$ \\
Tc & $13.58 \mathrm{a}$ & $33.09 \mathrm{a}$ \\
\hline
\end{tabular}


Means with the same letter are statistically equal $(\mathrm{p}<0.01)$

Regarding the AUDPC of early blight (caused by Alternaria solani), which affected only the main season planted plot (Pico central) from week 11, there was a significant $(\mathrm{p}<0.05)$ difference between the AUDPC of Alternaria solani in the conventional strategy $\mathrm{T}_{\mathrm{c}}$ and the organic strategy $\mathrm{O}_{2}$ (Table 9). The conventional strategy reduced the AUDPC compared to the organic strategy $\mathrm{O}_{2}$ by almost $60 \%$. The tubers harvested in the main season planted plot presented a significantly higher severity of infection of silver scurf
(Helminthosporium solani) (Table 10). In contrast, there was no relation between planting date and severity on tubers for rhizoctonia blight (Rhizoctonia solani). In both plots the harvested tubers did not present any sign of late blight (Phytophthora infestans) infection. There was no significant relation between the different treatments $\mathrm{T}_{c}, \mathrm{O}_{1}, \mathrm{O}_{2}$ and $\mathrm{T}_{0}$ and severity of tuber infection by black scurf (Rhizoctonia solani) and silver scurf (Helminthosporium solani).

Table 9. Area under disease progress curve (AUDPC) for early blight (Alternaria solani) on the potato landrace "pintaboca', assessed under four control strategies in the main planting season.

\begin{tabular}{ll}
\hline & AUDPC early blight \\
\hline Strategy & Main planting \\
\hline $\mathrm{O} 1$ & $55.95 \mathrm{ab}$ \\
$\mathrm{O} 2$ & $61.24 \mathrm{~b}$ \\
$\mathrm{~T} 0$ & $55.55 \mathrm{ab}$ \\
Tc & $28.51 \mathrm{a}$ \\
\end{tabular}

Means with the same letter are statistically equal $(\mathrm{p}<0.01)$

Table 10. Severity of tuber damage caused by black scurf and silver scurf under four cultivation strategies in two planting dates.

\begin{tabular}{llll}
\hline Planting time & Strategy & Silver scurf & Black scurf \\
\hline Early & O1 & $0.568 \mathrm{a}$ & $2.300 \mathrm{a}$ \\
Early & $\mathrm{O} 2$ & $0.589 \mathrm{a}$ & $3.225 \mathrm{a}$ \\
Early & T0 & $0.500 \mathrm{a}$ & $2.500 \mathrm{a}$ \\
Early & Tc & $0.762 \mathrm{a}$ & $2.325 \mathrm{a}$ \\
Main season & O1 & $3.316 \mathrm{~b}$ & $2.800 \mathrm{a}$ \\
Main season & O2 & $3.516 \mathrm{~b}$ & $2.525 \mathrm{a}$ \\
Main season & T0 & $3.197 \mathrm{~b}$ & $2.250 \mathrm{a}$ \\
Main season & Tc & $2.367 \mathrm{~b}$ & $1.825 \mathrm{a}$ \\
\hline
\end{tabular}

Means with the same letter are statistically equal $(\mathrm{p}<0.01)$ 
Revista Latinoamericana de la Papa 21 (1): 22 - 38

http://www.papaslatinas.org/revista.html

\section{Participatory evaluation of the harvest}

The strategy preferred by the farmers was $\mathrm{T}_{0}$, as it required less input of products and work while providing comparable yields to the organic strategies. This was followed by the organic treatment $\mathrm{O}_{2}$, the organic treatment $\mathrm{O}_{1}$ and finally the conventional treatment $T_{c}$. Statistically there is a highly significant preference for $\mathrm{T}_{0}$ against the other strategies, while there is not a significant difference between the strategies $\mathrm{O}_{1}, \mathrm{O}_{2}$ and $\mathrm{T}_{\mathrm{c}}$ (Table 11). Among the reasons stated by the farmers for their preference for the control $\mathrm{T}_{0}$ were: "it's healthy", "the potatoes do not have diseases", "there is no waste of money", "it has produced without use of chemicals". Reasons for ranking $\mathrm{O}_{2}$ at the second place: "it produces bigger and more than $\mathrm{O}_{1}$ ", "because it uses cattle manure instead of chicken manure", "it required more products, but it is affected by pests more than $\mathrm{T}_{0}$ ". Reasons for ranking $\mathrm{O}_{1}$ at the third place: "it costs more than the $\mathrm{O}_{2}$ ". Reasons for ranking $\mathrm{T}_{\mathrm{c}}$ at the fourth place: "because chemicals damage the environment", "because chemicals affect our health and nature", "it is more poisoned".

Table 11. Means of farmers' degree of preference of the four strategies.

\begin{tabular}{lc}
\hline Strategy & Average rank \\
\hline O1 & $2.8 \mathrm{a}$ \\
$\mathrm{O} 2$ & $2.4 \mathrm{a}$ \\
$\mathrm{T} 0$ & $1.0 \mathrm{~b}$ \\
$\mathrm{Tc}$ & $3.8 \mathrm{a}$ \\
\hline
\end{tabular}

Means with the same letter are statistically equal $(\mathrm{p}<0.01)$

\section{Economic considerations}

Considering the average market price in Colomi and Cochabamba for each potato size category in 2013 (Table 12), the total profit for each strategy was calculated for the harvest of the early planted plot (Table 13). The profit would be 25339.2 BOB ha ${ }^{-1}$ for the organic strategy $\mathrm{O}_{1}$, 28141.4 $\mathrm{BOB} \mathrm{ha}^{-1}$ for the organic strategy $\mathrm{O}_{2}, 28884.0$ BOB $\mathrm{ha}^{-1}$ for the control treatment $\mathrm{T}_{0}$ and $43177.6 \mathrm{BOB} \mathrm{ha}{ }^{-1}$ for the conventional strategy $\mathrm{T}_{\mathrm{c}}$. The conventional strategy has a higher yield per hectare and is the only strategy that produces the potatoes of size "chapara", which have the highest price on the market. Therefore, in order for organic strategies $\mathrm{O}_{1}$ and $\mathrm{O}_{2}$ and the control treatment $\mathrm{T}_{0}$ to provide the same profit per hectare as the conventional treatment, a price increase or "organic bonus" of $42 \%, 33 \%$ and $32 \%$ respectively would be necessary. 
Table 12. Prices for $100 \mathrm{~kg}$ of potatoes by size cathegory*.

\begin{tabular}{lllll}
\hline Chapara & Colque & Machu Murmu & Ch'ili Murmu & Ch'ili \\
\hline 5250 & & $(\mathrm{BOB} / 100 \mathrm{~kg})$ & & \\
\hline
\end{tabular}

* average between the price in the market in Colomi and Cochabamba in 2013

Table 13. Potential revenue per hectare for each strategy of the early planted plot according to 2013 local market prices and the percentage price increase necessary for organic potatoes to obtain the same profit per hectare as the conventional treatment tested.

\begin{tabular}{llllllllll}
\hline Chapara & Qolque & $\begin{array}{l}\text { Machu } \\
\text { Murmu }\end{array}$ & $\begin{array}{l}\text { C'hili } \\
\text { Murmu }\end{array}$ & Ch'ili & $\begin{array}{l}\text { Revenue } \\
\text { /ha }\end{array}$ & Cost/ha & Profit & $\begin{array}{l}\text { Organic } \\
\text { price } \\
\text { increase }\end{array}$ \\
\hline \multicolumn{7}{c}{} & & \multicolumn{7}{c}{ (BOB/ha) } \\
\hline O1 & 0.0 & 19981.5 & 11778.8 & 9265.5 & 1742.0 & 42767.8 & 17428.6 & 25339.2 & $42 \%$ \\
O2 & 0.0 & 23667.0 & 10606.5 & 8592.8 & 2418.0 & 45284.3 & 17142.9 & 28141.4 & $33 \%$ \\
T0 & 0.0 & 23019.5 & 11468.3 & 7582.5 & 2528.0 & 44598.3 & 15714.3 & 28884.0 & $32 \%$ \\
Tc & 22916.3 & 20184.5 & 10388.3 & 5269.5 & 1562.0 & 60320.5 & 17142.9 & 43177.6 & 0 \\
\hline
\end{tabular}

\section{Discussion}

Planting earlier resulted in significantly higher yields. The Area Under Disease Progress Curve (AUDPC) of Phytophthora infestans, which is a summary of disease severity, did not significantly differ between planting dates, but the plot planted in the main season, i.e. the traditional practise, was additionally infected by early blight Alternaria solani.

So, the early planting per se did not decrease the severity of late blight, but shifted the bulking phase of the potatoes to an earlier point, allowing the plants to produce tubers for a longer time before the infection of Phytophthora infestans and Alternaria solani stopped further tuberization. In fact, according to Large (1952) mentioned in Chaube and Pundhir (2005), "Studies on mean bulking curves (MBC) revealed that further tuberization stops once $75 \%$ of the foliage has been damaged. However, for certain other cultivars this value was reported to be $40-50 \%$ ". Tuberization in the landrace 'pintaboca' (Solanum stenotomum) starts approx. 78 DAP, simultaneously with the appearance of the first flowers, and the potato plants in the area have a life cycle of 155-166 days (Patiño et al., 2003). In the early planted plot late blight was first recorded 100 days after planting and reached $75 \%$ severity around 150 days after planting. In the plot planted in October, early blight was first recorded 69 days after planting and the disease reached $75 \%$ severity around 123 days after planting. The late planted plot had a considerable shorter healthy period of tuberization, which explains the minor yields obtained.

Variation in yield between different planting times might also have been influenced by the quality and the previous use of the soil as the experiments were carried out at two different locations (Balcon and Pico Central). The soil in 
Balcon had a higher sand content and higher organic matter and nitrogen content (Table 1). Moreover, the early planted plot in Balcon had previously been left fallow for more than 5 years, while the plot in Pico Central was cultivated with the tuber crops oca (Oxalis tuberosa) and papalisa (Ullucus tuberosus) the year before.

During the growth period of the plot in Pico Central (main season planting) it was noted that plants from the residual tubers of oca and papalisa from the previous season were growing in the rows of the experiment and they had to be removed regularly as weeds. The competition for nutrients with these 'residual' plants might have led to a negative effect on the growth of our potato crop.

It would have been ideal to carry out the experiment at only one location, but working under field conditions we had to adapt to the availability of land provided by the farmers. This is of course not ideal and future experiments are recommended to be carried out at one site only and for consecutive years, to establish more accurately the influence of planting time on yields.

A significant effect of the strategies adopted $\left(\mathrm{O}_{1}, \mathrm{O}_{2}, \mathrm{~T}_{0}\right.$, and $\left.\mathrm{T}_{\mathrm{c}}\right)$ for plant protection (in terms of AUDPC of Phytophthora infestans) was noted only in the early planted plot and even in this case only the $T_{c}$ differed significantly from the control $\mathrm{T}_{0}$. Hence, the alternate use of Biobacillus and Terrabiosa and of Timorex and Terrabiosa did not prove to have any effect on the plants and therefore cannot be suggested as valid anti-fungicides to the farmers with the dosage tested.

Our results in the early-planted experiment, reported no significant total yield difference between the organic, the conventional and the control strategies. The only difference between strategies was that tubers of the largest size 'Chapara', i.e. on average $14.5 \mathrm{~cm}$ long, were produced by the plants cultivated under conventional Tc treatments only. If the potatoes had to be used to produce organic potato crisps, the industry should be adverted that the largest size category obtainable according to our experiment would be the 'Machu murmu'. Instead the smallest sizes of organic potatoes could be sold to high-end restaurants, which require the smallest sized categories, sold as 'gourmet potatoes' (Hugo Bosque, pers. comm.). Also in the main season planted experiment there was not a significant difference between the yields of conventional and organic agriculture (Table 6). Although, in this case, the plants were highly affected first by the attack of Alternaria solani and then by Phytophthora infestans and none of the strategies gave satisfactory yields.

Local farmers who participated in the evaluation of the harvest, seeing no considerable difference between the results of the conventional, organic and the control plots, stated that they would not apply any of the tested organic products to be used as foliar spray the following year. Instead, they were interested in using the $\mathrm{T}_{0}$ strategy because, according to them, this would save time, money and effort while producing similar yields to the organic strategies $\mathrm{O}_{1}$ and $\mathrm{O}_{2}$, while being more healthy than the conventional. The $\mathrm{T}_{0}$ strategy was also the one that would need the least price increase $(32 \%)$ in order to produce the same profit per hectare as the conventional. Economic profitability of the organic treatments might be increased with improved nutrient management. In an experiment with the potato landrace 
"waycha", the application of the organic foliar spray Fertisol (produced by PROINPA) with a frequency of three times during the growing season, increased the production of the tubers of the largest size Chapara by $33 \%$ (Mamani et al., 2016). It would be interesting to test the production and the relative economic viability with the introduction of this product, as under the current treatments no size 'Chapara' was produced in the organic strategies, while this is the most valuable category on the market.

\section{Conclusion}

From the results of this study we recommend early planting as a management strategy for organic cultivation of the landrace 'pintaboca' in Colomi at average altitudes of 3,330 m.a.s.l. Nevertheless, further studies are necessary to repeat the experiment of planting in August against planting in October with plots in the same location.

In order to test the effectiveness of the products Tricobal and Mibac that here were applied simultaneously at planting, another experiment should be made testing each product separately and with higher concentrations against a control with no application. The same setup should be conducted for the biofungicides applied on the foliage.

\section{Conflict of interests}

The authors declare there is no conflict of interest in the publication of the results of this research.

\section{Acknowledgements}

We are most grateful to the farmers Casto Carballo and Hugo Porrez and their families, who provided the land and part of the labor for the experiment. Thanks to the colleagues from PROINPA Cochabamba, especially Gonzalo Tiñini
Huanca, Rhimer Gonzales and Mayra Claros for support in the field and laboratory. The study was financed by the University of Copenhagen through the grant conceded to the Ph.D. Candidate Gaia Luziatelli.

\section{References}

Altieri, M.A. 1999. The ecological role of biodiversity in agroecosystems. Agric Ecosyst Environ, 74, 19-31.

Bengtsson, J.; Ahnström, J.; Weibull, A.C. 2005. The effects of organic agriculture on biodiversity and abundance: A meta-analysis. J App Ecol, 42, 261-269.

Borriss, R. 2011. Use of Plant-Associated Bacillus Strains as Biofertilizers and Biocontrol Agents in Agriculture. In: Bacteria in Agrobiology: Plant Growth Responses (edited by K.D. Maheshwari). Pp. 41-76. Berlin, Heidelberg: Springer Berlin Heidelberg.

Cadima, X.; Gonzales, R.; Almanza, J.; Garcia, W.; Terrazas, F. (Eds.). 2004. Catálogo de variedades locales de Papa y Oca de la zona de Candelaria. Cochabamba, Bolivia: Fundación para la Promoción e Investigación de Productos Andinos, Municipio de Colomi, Centro Internacional de la Papa, Agencia Suiza para el Desarrollo y la Cooperación.

Chaube S., H.; Pundhir, U.S. 2005. Crop Diseases and Their Management. 2nd edn. New Delhi, 724 p: PHI Learning Private Limited.

Chowdappa, P.; Mohan Kumar, S.P.; Jyothi Lakshmi, M.; Upreti, K.K. 2013. Growth stimulation and induction of systemic resistance in tomato against early and late blight by Bacillus subtilis OTPB1 or Trichoderma harzianum OTPB3. Biological Control, 65, 109-117.

Coca-Morante, M. 2012. Las papas en 
Bolivia. Bolivia: Universidad Mayor de San Simón, Facultad de Ciencias Agrícolas, Pecuarias, Forestales y Veterinarias 'Dr. Martín Cárdenas H.'. Cochabamba.

Cole, D.C.; Orozco T. F.; Pradel, W.; Suquillo, J.; Mera, X.; Chacon, A.; Prain, G.; Wanigaratne, S.; Leah, J. 2011. An agriculture and health inter-sectorial research process to reduce hazardous pesticide health impacts among smallholder farmers in the Andes. BMC Int Health Hum Rights, 11, S6.

Donaire-Eguívar, R.; Garcia, W. 2006. Alternativa agroecológica para el control del tizón tardío, Phytophthora infestans, de la papa en Colomi - Bolivia. ACTA NOVA, 3, 564-577.

Franco, J.; Main, G.; Navia, O.; Ortuño, N.; Herbas, J. 2011. Improving Productivity of Traditional Andean Small Farmers by Bio-Rational Soil Management: I. The Potato Case. Revista Latinoamericana de la Papa, 16, 270-290.

Gabriel, J.; Ortuño, N.; Franco, J.; Plata, G.; Angulo, A.; Magne, J. 2010. Manual metodológico para la evaluación de resistencia y/o susceptibilidad de factores bióticos y abióticos en papa (Solanum tuberosum L.). Fundación PROINPA, Cochabamba, Bolivia 19 p.

García, W.; Cadima, X.; Terrazas, F.; Gandarillas, A. 2003. La Agrobiodiversidad Sostenible: Conservación In Situ Y Ex Situ. Manejo sostenible de la agrobiodiversidad de tubérculos andinos: Síntesis de investigaciones y experiencias en Bolivia, $1-12$.

Haverkort, A.J.; Struik, P.C.; Visser, R.G.F.; Jacobsen, E. 2009. Applied Biotechnology to Combat Late Blight in Potato Caused by Phytophthora infestans. Potato Res, 52, 249-264.
Henfling, J.W. 1987. Late Blight of Potato. Phytophthora infestans. CIP Technical Information Bulletins.

Kloepper, J.W.; Ryu, C.-M.; Zhang, S. 2004. Induced Systemic Resistance and Promotion of Plant Growth by Bacillus spp.. Phytopathology, 94, 1259-1266.

Kuepper, G.; Sullivan, P. 2004. Organic Alternatives for Late Blight Control in Potatoes. ATTRA-National Sustainable Agriculture Information Service http://www.attra.ncat.org/attrapub/lateblight.html.

Large, E.C. 1952. The interpretation of progess cumer for potato blight and other plant disease. Plant Pathol, 1, 109-117.

Madden, L.V; Hughes, G.; Bosch, F. van den. 2007. The Study of Plant Disease Epidemics. St. Paul, 432 p: APS Press.

Mäder, P.; Fliessbach, A.; Dubois, D.; Gunst, L.; Fried, P.; Niggli, U. 2002. Soil fertility and biodiversity in organic farming. Science (New York, N.Y.), 296, 1694-1697.

Mamani-Rojas, P.; Limachi-Villalba, J.; Ortuño-Castro, N. 2012. Uso de microorganismos nativos como promotores de crecimiento y supresores de patógenos en el cultivo de la papa en Bolivia. Revista Latinoamericana de la Papa, 17 (1), 74-96.

Mamani, E.; Morales, V.; Ortuño, N. 2016. Aplicación de biofertilizantes foliares en el cultivar Huaycha (Solanum tuberosum subsp. andigena) en los valles interandinos de Bolivia. Revista Latinoamericana de la Papa, 20 (2), 1425.

Manrique, K.; Thomann, A.; Ordinola, M.; Bernet, T.; Devaux, A. 2011. T'ikapapa: A marketing scheme that uses potato biodiversity to improve livelihoods of Andean farmers in Peru. In: Innovation 
for Development: The Papa Andina Experience. (edited by A. Devaux, M. Ordinola and D. Orton). Pp. 161-179. Lima, Peru: International Potato Center.

Orozco, F.A.; Cole, D.C.; Forbes, G.; Kroschel, J.; Wanigaratne, S.; Arica, D. 2009. Monitoring adherence to the international code of conduct: highly hazardous pesticides in central Andean agriculture and farmers' rights to health. International Journal of Occupational and Environmental Health, 15, 255-68.

Ortuño, N.; Navia, O.; Medrano, A.; Rojas, K.; Torrico, L. 2010. Desarrollo de bioinsumos: un aporte a la soberania alimentaria de Bolivia. Revista de Agricultura, 62, 30-38.

Patiño, F.; Gonzáles, S.; Iriarte, V.; Ramos, J. 2003. Manejo Agronómico de los cultivos de Oca, Papalisa e Isaño. pp. 99-110. In: Cadima, X.; Garcia, W. (eds.), Manejo sostenible de la agrobiodiversidad de tubérculos andinos: Síntesis de investigaciones y experiencias en Bolivia. PROINPA, Cochabamba. 197 p.

Senamhi. 2013. Lluvia registrada en estacion metereologica Colomi 20122013.

http://www.senamhi.gob.bo/sismet/index. php. Accessed 28/04/2017.

Stephan, D.; Schmitt, A.; Carvalho, S.M.; Seddon, B.; Koch, E. 2005. Evaluation of biocontrol preparations and plant extracts for the control of Phytophthora infestans on potato leaves. Eur J Plant Pathol, 112, 235-246.

Sullia, S.B. 1991. Use of Vesicular Arbuscular Mycorrhiza (VAM) as Biofertilizer for Horticultural Plants in Developing Countries. In: Prakash J.; Pierik, R.L.M. (eds.) Horticulture - New Technologies and Applications: Proceedings of the International Seminar on New Frontiers in Horticulture, organized by Indo-American Hybrid Seeds, Bangalore, India, November 2528, 1990. Springer Netherlands, Dordrecht. Pp. 49-53.

Zeballos, H.; Balderrama, F.; Condori, B.; Blajos, J. 2009. Economía de la Papa en Bolivia (1998-2007). Cochabamba, Bolivia: Fundación PROINPA. 